\title{
The establishment of apple orchards as temperate forest garden systems and their impact on indigenous bacterial and fungal population abundance in Southern Ontario, Canada
}

\author{
P.C. Wartman ${ }^{1 *}$, K.E. Dunfield ${ }^{2}$, K. Khosla ${ }^{2}$, C. Loucks ${ }^{1}$, R.C. Van Acker ${ }^{1}$ and R.C. Martin ${ }^{1}$ \\ ${ }^{1}$ Plant Agriculture, University of Guelph, Guelph, Ontario, Canada. \\ ${ }^{2}$ School of Environmental Sciences, University of Guelph, Guelph, Ontario, Canada. \\ ${ }^{*}$ Corresponding author: wartmanpaul@gmail.com
}

\begin{abstract}
This research investigated soil microbial abundances affected by different ground management systems in establishing apple (Malus domestica cv. Idared, M9) orchards in Ontario, Canada. Four treatments, including forest garden systems with and without compost (FGSC and FGS), and grass understory systems with and without compost (GC and G), were assessed over two establishment years for gene copy abundance of soil arbuscular mycorrhizal (AM) fungi, total fungi and total bacteria using quantitative real-time polymerase chain reactions. Time had a greater effect on all three soil microbial abundances, with total bacterial and AM fungi decreasing and total fungal abundance increasing from spring 2013 to fall 2014. The changes were greatest between the sampling dates of fall 2013 and spring 2014, which is $1 \mathrm{yr}$ after the establishment of the experimental apple plots. There were no significant differences in soil microbial abundances between treatments at any specific sampling date. Apple tree trunk circumference was greatest for FGSC and FGS after $2 \mathrm{yr}$, but no significant differences in GC and G treatments. In the last sampling period, fall 2014, FGSC plots had significantly greater trunk circumferences compared with G plots. Soil chemical properties neither changed over the $2 \mathrm{yr}$, nor did they differ between treatments at any one sampling time. We conclude that the applebased FGS treatments can benefit apple tree growth and there is a basis for future research to explore specific plantplant, plant-microbe and microbe-microbe relations in FGSs.
\end{abstract}

Key words: forest garden system, agroforestry, temperate agriculture, microorganisms, apple orchards, organic matter, perennial polyculture

\section{Introduction}

Scientific disciplines such as landscape ecology, natural agriculture, permaculture and agroecology, in addition to indigenous knowledge, provide alternative frameworks within which agriculture is holistically designed placing emphasis on diverse perennial vegetation to meet the needs of a growing human population while sustaining, and potentially restoring, natural systems (Jackson, 2002; Wu and Hobbs, 2002; Tomich et al., 2011; Ferguson and Lovell, 2014).

One such agricultural system is a forest garden system (FGS). An FGS can be described simply as 'a perennial polyculture of multipurpose plants' (Jacke and Toensmeier, 2005). Similar to some agroforestry concepts, FGSs are designed primarily with diverse, multi-strata perennials and self-sowing annuals that mimic the structure of natural forest, woodland and savannah ecosystems. Modern temperate FGSs were inspired by tropical FGSs, which were established by local indigenous communities with goals of sustenance, income from local and export markets, and conserving the forests on which they depend for a livelihood (Wiersum, 2004; Butt et al., 2015). Other goals of modern temperate FGSs include achieving a state of abundant diverse yields, self-fertilization, self-maintenance and selfrenewal (Wiersum, 2004; Jacke and Toensmeier, 2005). 
FGSs are designed with the intention to serve the longterm needs of the whole system, not just the short-term needs of a single species. This is attempted through the implementation of ecosystem service-based components mimicking regionally appropriate ecosystem models, such as forests for apples (Janick, 2003). Plant species diversity is an integral component of forest ecosystems that encourages stability coinciding with productivity (Kimmins, 2004). Diverse perennial plants contribute to ecosystem functions through nutrient accumulation, carbon (C) sequestration, water storage and filtration, production of food (e.g., fruits, nuts, greens, sugars and fodder), medicine and other yields for human use, as well as habitat creation and shelter (Thevathasan and Gordon, 2004; Jose, 2009; Uprety et al., 2012; Nerlich et al., 2013; Wotherspoon, 2014). These contributions help to restore ecosystem functions and mitigate and adapt to effects of damaging agricultural practices.

Microorganisms drive ecosystem productivity and affect nutrient cycling (e.g., nitrogen $(\mathrm{N})$, phosphorus (P) and C), plant symbiotic relations, plant growth and soil structure (Allen et al., 2003; Smith and Smith, 2011; Whiteside et al., 2012). Recent research is providing insight into how agricultural practices can support microorganisms to increase ecosystem services with possibilities to reduce the use of external inputs (Zak et al., 2003; Welbaum et al., 2004; Bonfante and Anca, 2009; Smith and Smith, 2011).

Apple orchards are an example of temperate agricultural systems that could adopt FGS principles, specifically diverse plants and microorganism function, to potentially increase overall yields of the system while reducing the negative effects of cultivation and fossil fuel-based inputs. There are few studies that have measured the effects that diverse plants as living and/or organic mulches in orchards have on soil microorganisms.

Holistic orchard management research is developing practices to reduce $\mathrm{N}$ inputs, mitigate nutrient loss, promote productivity and manage weeds and disease through the implementation of practices that support ecosystem services (Hoagland et al., 2008; Granatstein and Sanchez, 2009; Brown, 2012).

Apple orchards are conventionally managed at low levels of diversity with system priority given primarily to the production of apples. Hoagland et al. (2008) demonstrated this approach by planting an organic apple orchard with a single variety on one type of rootstock at spacing of $1.5 \mathrm{~m}$ in parallel rows that were separated by $4 \mathrm{~m}$ in a location previously planted to cherries. In these systems, pesticides and continuous cultivation are used to manage vegetation, soil microbes and animals, thereby maintaining a state that best produces apples. For example, in two respective orchards unwanted plants in the understory were killed via a combination of three herbicides (glyphosate, norflurazon and diuron) applied in early spring each year (Yao et al., 2005), and soil tillage was performed 'as needed' for weed control to prevent competition to newly established apple trees (Hoagland et al., 2008). Leinfelder and Merwin (2006) described older apple orchards being replanted with apples, sometimes continuously for more than a century. Also, in approximately $50 \%$ of New York, USA, fruit growers experience replant disease, which results in reduced tree health and, depending on the region and practices used, develops from a combination of varying levels of nutrient imbalances, soil compaction, the presence of particular fungi, bacteria, and nematodes, and herbicide residue buildup (Leinfelder and Merwin, 2006).

Hoagland et al. (2008) studied multiple methods of organic orchard ground management systems ranging from cultivation with compost amendments, to wood chip and living mulches. They found that increased compost additions $(5.4$ and $8.1 \mathrm{~kg}$ ) with cultivation as a form of short-term nutrient supply did not change the soil microbial activity (nor did it affect tree growth) compared with the control treatment with a lower compost application $(2.7 \mathrm{~kg})$, whereas living mulch treatments (mix of broadleaf and grass species) measured significantly higher in dehydrogenase activity, $\mathrm{C}$ mineralization, $\mathrm{CO} 2$ production and nematode numbers. Compost applied at the control treatment rate of $2.7 \mathrm{~kg}$ met the early growth needs of apple trees compared with the higher compost application rates (5.4 and $8.1 \mathrm{~kg}$ ), which did not increase tree growth (Hoagland et al., 2008).

Another study showed that the number of colonyforming units (CFU) for fungi in grass (red fescue (Festuca rubra L.)) understory treatments, which, due to existing soil seed bank, invasion of other seeds, and lack of weed control, developed into a mixture of about 25 herbaceous species, was significantly greater $(\sim 200 \%)$ than treatments with just bark mulch or herbicide use (Yao et al., 2005). In the same study, bacteria numbers were similar over most treatments, except for the treatment in which pre-emergent herbicides were used, where numbers were significantly lower. Although Yao et al. (2005) presented significant differences, it's important to note that the use of cultured-based methodologies for measuring microbe composition is under-representative because only a small portion $(1-10 \%)$ of bacteria and fungi can be cultured in laboratory media reliably (Hirsch et al., 2010).

These studies showed that living understories and organic mulches in orchards affect soil microorganisms, specifically by increasing their abundance and activity. These practices also resulted in increased soil nutrients and tree growth.

Hoagland et al. (2008) discussed a need for management succession strategies that implement living understories in a way that reduces competition to the main crop during sensitive establishment growth years and that matures into self-sufficiency. This concept is similar to FGSs and tends to implement diverse plant structures, species, functions and interactions. Continued research into how diverse perennial orchard management 
systems, such as FGS, affect soil microorganism interactions over time is needed to increase our understanding of and to demonstrate practical models for holistic orchard management.

The purpose of this study was to initiate research in temperate FGSs with goals of measuring the effects that establishing an apple-based FGS with varying amounts of compost has on the abundance of soil bacterial and fungal communities in Southern Ontario, Canada. The null hypothesis is that newly established apple-based FGS and newly established apple trees with mixed-grass understories, both with and without compost, will have the same shift in soil bacterial and fungal population abundance, SOM, tree growth and soil chemistry over $2 \mathrm{yr}$. The specific objectives of this study were to measure and compare: (1) the abundance of total bacterial, total fungal and arbuscular mycorrhizal fungal (AMF) gene copies in the soil, (2) soil organic matter (SOM), (3) apple tree growth and (4) soil chemical properties (i.e. $\mathrm{pH}$ and the nutrients potassium $(\mathrm{K})$, magnesium $(\mathrm{Mg}), \mathrm{P})$, between newly established apple-based FGS plots and grass understory managed apple plots, both with and without compost.

\section{Materials and Methods}

\section{Site description}

This study was carried out in 2013 and 2014 at three sites in Southern Ontario, all of which have soils that are Luvisols with a loam texture (40\% sand, $40 \%$ silt and $20 \%$ clay).

(1) Guelph Centre for Urban Organic Farming at the

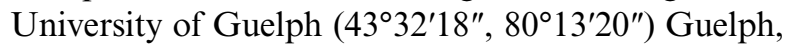
Ontario; 1 ha of urban agricultural land established in 2008 and managed organically. The Guelph area has a mean annual temperature of $6.5^{\circ} \mathrm{C}$ and a mean annual precipitation of $923 \mathrm{~mm}$ (Government of Canada, 2015). This site has a Canadian Land Inventory of 3, which rates from 1 , the highest, to 7 , the lowest, the capacity of land to support agricultural land use practices. The soil here has a $\mathrm{pH}$ of 7.2 and SOM of $4.9 \%$. This experimental site was previously planted to mixed perennial vegetables, which were managed organically, and was within $10 \mathrm{~m}$ of a mixed forest ecosystem as well as $200 \mathrm{~m}$ away from multiple apple tree varieties.

(2) Ignatius Farm $\left(43^{\circ} 34^{\prime} 10^{\prime \prime}, 80^{\circ} 17^{\prime} 24^{\prime \prime}\right)$, Guelph, Ontario; 242 ha of agricultural land and a conservation area which has been managed organically for the past $100 \mathrm{yr}$, at least. The climate conditions are the same as site 1 and the soils have a Canadian Land Inventory of 3, a $\mathrm{pH}$ of 7.5 and soil $\mathrm{OM}$ of $3.8 \%$. This experimental site was previously planted to mixed annual vegetables, which were managed organically, and was within $10 \mathrm{~m}$ of a woody vegetated wetland as well as $10 \mathrm{~m}$ from crab apple trees and $150 \mathrm{~m}$ from many varieties of apples.

(3) Iceland Teaching Garden at Ecosource's Community Garden $\left(43^{\circ} 37^{\prime} 32^{\prime \prime}, 79^{\circ} 39^{\prime} 10^{\prime \prime}\right)$ Mississauga, Ontario; a quarter-hectare urban garden that has been under organic production practices for the past $2 \mathrm{yr}$. The greater Toronto area has a mean annual temperature of $9.4^{\circ} \mathrm{C}$ and a mean annual precipitation of $831 \mathrm{~mm}$ (Government of Canada, 2015). This site has a Canadian Land Inventory of 1 , soils that have a $\mathrm{pH}$ of 7.4 and soil $\mathrm{OM}$ of $3.7 \%$. This experimental site was previously planted to mixed annual vegetables, which were managed organically, and were within $10 \mathrm{~m}$ of a woody vegetated wetland as well as $50 \mathrm{~m}$ of crab apple trees.

All sites were tilled early spring 2013 in preparation for planting. Apple trees (Malus domestica cv. Idared on M9 rootstocks) were planted in May 2013 at all three sites as $1 \mathrm{yr}$ bare roots and pruned from an average height of $153 \mathrm{~cm}$ down to $106 \mathrm{~cm}$ high. The particular cultivar and rootstock were chosen as a result of availability at that time. Thirty-two trees were planted between the sites: eight at Iceland Teaching Garden, 12 at Guelph Centre for Urban Organic Farming and 12 at Ignatius Farm.

\section{Experimental design}

The experiments at each site were set up as a completely randomized design with two, three and three replicates of four ground management system treatments at the respective sites, Iceland Teaching Garden, Guelph Centre for Urban Organic Farming, Ignatius Farm (Figure 1), with goals to compare the effects of different levels of plant diversity and compost addition on soil microbial abundance, tree growth and soil properties. Due to similarity in soil types across all three sites, the data were analyzed collectively.

The plots consisted of respective $1.5 \mathrm{~m} \times 4.5 \mathrm{~m}$ $\left(6.75 \mathrm{~m}^{2}\right)$ experimental units of soil with one apple tree and one treatment in each unit. The four treatments were as follows: (1) G: an equal mix of three grasses, e.g. Kentucky blue (Festuca arundinacea cv. Schreb.), creeping red fescue (F. rubra L.) and perennial rye grass (Lolium perenne L.), was hand broadcast in spring each year for better establishment and a $15 \mathrm{~cm}$ layer of coarse softwood chip mulch was laid only around the root zone of the apple tree $\left(0.75 \mathrm{~m}^{2}\right)$; (2) GC: same as G with $2.7 \mathrm{~kg}$ (Hoagland et al., 2008) of organically certified turkey litter compost (Cold Springs Farm, Guelph, Ontario, Canada; $1.02 \%$ N, $19.06 \%$ OM, $1.31 \% \mathrm{P}, 0.72 \% \mathrm{~K}$ and a $\mathrm{C}: \mathrm{N}$ ratio of 10.6 ) applied around the root zone of the apple tree as a single application in the first year (Figure 2); (3) FGS: forest garden system, holistically designed understory of diverse, perennial support plants (comfrey (Symphytum $x$ uplandicum cv. Blocking 14), chives (Allium tuberosum cv. Rottler ex 


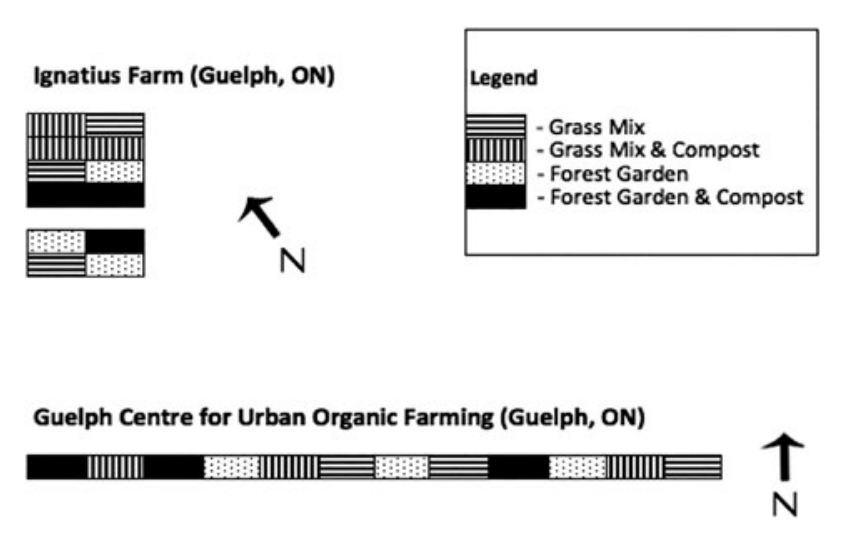

Ecosource Iceland Teaching Garden (Mississauga, ON)

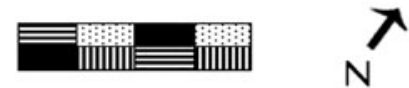

Figure 1. Completely randomized design of three experimental sites presenting the layout of replicated treatments. At Ignatius Farm there was an area $(3 \times 3 \mathrm{~m})$ of organic annual veg production between two areas of the experiment.

Spreng), sorrel (Rumex acetosa L.), lupins (Lupinus perennis L.), white clover (Trifolium repens L.), mint (Mentha $x$ piperita L. cv. Chocolate Mint), bergamot (Monarda fistulosa L.), onion (Allium proliferum cv. (Moench) Schrad, ex Willd) and Siberian pea shrub (Caragana arborescens Lam.) (Shortt and Vamosi, 2012), and a $15 \mathrm{~cm}$ layer of coarse softwood chip mulch around all plants $\left(2.25 \mathrm{~m}^{2}\right)$ (Hoagland et al., 2008); and (4) FGSC: same as FGS with $2.7 \mathrm{~kg}$ of organically certified turkey litter compost applied around the root zone of the apple tree as a single application in the first year. The plants in the forest garden-based treatments were chosen for their known functions, based on anecdotal and academic sources, and how these species might contribute to the ecology of this production system.

Aggressive perennials with multiple functions rather than annuals were selected for purposes of $\mathrm{N}$ fixation, nectary sources for pollinators and beneficial insects, and reduced weed competition and to prevent the need for cultivation. Eight plants in the forest garden-based treatments provide sources of nectar throughout the whole season, from April to October. Nitrogen-fixing plants, consisting of the Siberian pea shrub, white clover, and lupins, were planted to an area of $40 \%$ of the apple tree's mature canopy area (Crawford, 2012) and were spaced accordingly in regard to plant growth, sun position and shade development. Sorrel, lupine, and white clover, have been used as cover and catch crops to help fix $\mathrm{N}$ and reduce leaching of nutrients, as well as providing secondary crops for harvest (Askegaard and Eriksen, 2007). Mint and bergamot are used for thick sprawling growth patterns (Jacke

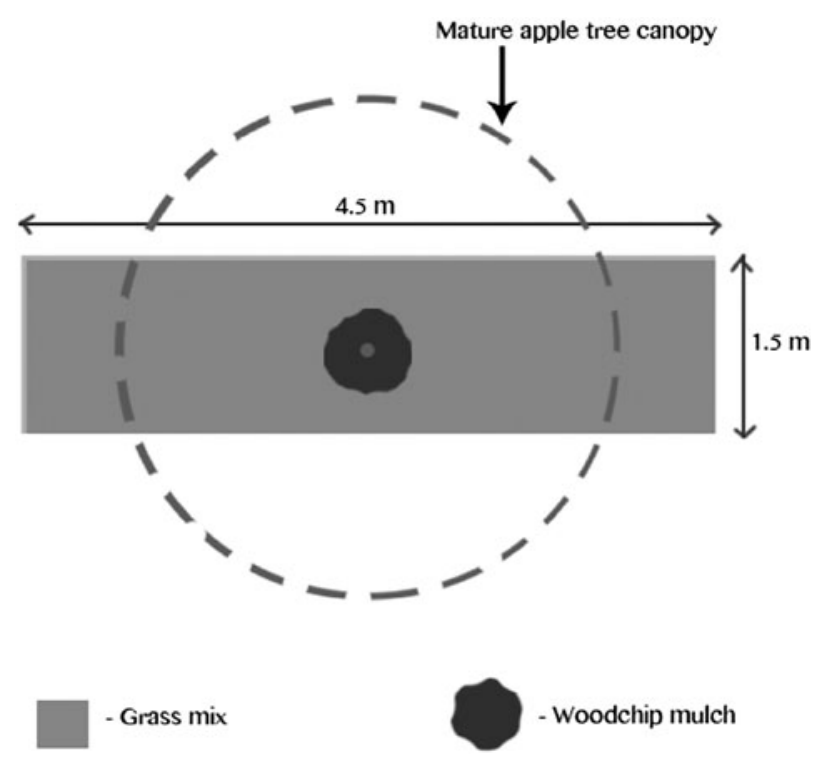

Figure 2. Perspective from above of experimental design of grass treatments with apple tree in center and mix of three grass species as understory.

and Toensmeier, 2005). Chives and onions can act as possible secondary crops, flowering plants for pollinators, and weed exclusion with clumping and sprawling growth patterns, respectively (Jacke and Toensmeier, 2005). Comfrey is an aggressive species that can create barriers to keep grass and other unwanted plants out of certain areas and it can be coppiced multiple times in a season for mulch purposes (Jacke and Toensmeier, 2005).

Unwanted plants in $\mathrm{G}$ and $\mathrm{GC}$ plots were manually mown bimonthly with a hand-held scythe and, in FGS and FGSC, unwanted plants were hand pulled in the first year and mulched with existing woodchips from within respective plots in the second year. Woodchip mulch was only applied from an external source in spring 2013. No fertilizers, other than compost, nor pesticides were used prior to planting for bed maintenance or during management over the $2 \mathrm{yr}$.

Apple trees were measured for growth and herbivorous damage. Tree trunk circumferences $15 \mathrm{~cm}$ above grafting point were measured before planting and at the end of the second growing season, fall 2014. Herbivore-related damage was measured by rating the damage to foliage, including young branches, and trunk from 0 to 10 at the end of each season (November 2013 and 2014). Vole, rabbit and other small mammal herbivore damage to apple trees, which mostly occurred as trunk bark damage, was deterred with reusable plastic spiral wraps. Deer herbivore damage was deterred with bird netting and stakes around individual trees, to little avail, and larger permanent exterior fencing at the Mississauga site. Insect herbivore damage was measured and then the pest was stripped by hand if the tree was at risk of death (only occurred once in the first year). 
Table 1. Primers, sequences, target genes, literature sources and organism names for the qPCR process.

\begin{tabular}{|c|c|c|c|}
\hline Primer & Sequence $\left(5^{\prime}-3^{\prime}\right)$ & Target gene & $\begin{array}{l}\text { (Literature source) and Organism } \\
\text { name for cloning standard curve }\end{array}$ \\
\hline $\begin{array}{l}\text { bac16S } 338 f \\
\text { bac16 s } 518 r\end{array}$ & $\begin{array}{l}\text { act cct acg gga ggc agc ag } \\
\text { att acc gcg get gct gg }\end{array}$ & $16 \mathrm{~S}$ rRNA & (Fierer et al., 2005) Bacteroides fragilis \\
\hline$A M L 1$ & atc aac ttt cga tgg taggat aga & $18 \mathrm{~S}$ rRNA & (Lee et al., 2008) Fungi removed from \\
\hline$A M L 2$ & gaa ccc aaa cac ttt ggt ttc c & $18 \mathrm{~S}$ rRNA & Flacourtia jangomas roots \\
\hline$I T S 1-F$ & ctt ggt catt tag agg aag taa & Internal transcribed spacer region & (Gardes and Bruns, 1993) \\
\hline ITS4-B & cag gag act tgt aca cgg tcc ag & & Gaeumannomyces incrustans \\
\hline
\end{tabular}

\section{Soil sampling}

Soils in the respective plots were sampled four times, including a baseline before initial planting in May 2013 (spring 2013). The three subsequent samplings occurred in October/Novemeber (fall 2013), June 2014 (spring 2014) and October/November 2014 (fall 2014). All soil samples in this study were taken to a $10 \mathrm{~cm}$ depth with a stainless steel corer with a $1.5 \mathrm{~cm}$ diameter and at consistent locations over the four sampling periods at least $30 \mathrm{~cm}$ in from the borders of each plot. Ten composite soil samples were collected and combined per respective plot resulting in a total of 32 samples from 32 plots over the three sites per sampling date (e.g., $G$ treatments had a total of eight respective soil samples across all three sites per sampling period). Rocks and surface debris were manually removed and the samples were each sealed in a ziplock bag, and transported in a cooler with ice packs to a $4^{\circ} \mathrm{C}$ fridge. They were stored there for max $48 \mathrm{~h}$ until DNA extraction, and for up to $1 \mathrm{yr}$ until physical and chemical analyses. A sub-sample $(5 \mathrm{~g})$ of each plot's main soil sample was oven-dried in order to determine the gravimetric moisture content. All microbial data were adjusted to oven-dry weight equivalents.

\section{Nucleic acid extraction and quantitative polymerase chain reaction (qPCR)}

Total genomic soil DNA was extracted from 0.25 to $0.55 \mathrm{~g}$ of soil according to manufacturer's protocol manufacturer's protocol using the UltraClean ${ }^{\circledR}$ Soil DNA Isolation Kit (MoBio, Carlsbad, CA, USA). The DNA was stored at $-80^{\circ} \mathrm{C}$ until analysis.

A qPCR was performed to estimate abundance of AMF, total bacterial and total fungi. Primer pairs that target a segment of $A M L$ segment of $A M L$ (fungal 18S), bac16S (bacterial) and ITS (fungal) genes were used, respectively (Gardes and Bruns, 1993; Fierer et al., 2005; Lee et al., 2008). Primer sequences can be found in Table 1. All qPCR assays were performed with a Bio-Rad CFX detection CFX detection system (Bio-Rad Laboratories, Hercules, CA). Optimized cycling profiles were used from the aforementioned citations. For each $1 \mu \mathrm{DNA}$ template, reactions were performed in a total volume of $25 \mu \mathrm{l}$ per sample, with $12.5 \mu \mathrm{l}$ of $2 \times$ SoFAST Supermix, $10 \mu \mathrm{M}(10 \mathrm{pM} \mu \mathrm{l}-1)$ each forward and reverse primers, $1 \mu \mathrm{T} 4 \mathrm{~g} 32$, and RNase and DNase free water. Gene copy quantification was determined by fluorescence intensity of EVA Green dye. Melt curve analyses were performed for each respective gene to verify amplicon specificity. Polymerase chain reaction runs had average efficiencies of $90.5,89.4,105.9,94.2 \%$ and average $R^{2}$ values of $0.995,0.990,0.996$ and 0.996 for AML, bacterial 16S and fungal ITS genes, respectively. Each measurement was performed in one full set and notemplate controls in each run had undetectable amplification.

Serial dilutions of non-linearized plasmid DNA containing the target genes were used to construct standard curves (Table 1). PCR products of AMF, bacterial and fungi genes were cloned into One Shot ${ }^{\mathbb{B}}$ Top10 Escherichia coli competent cells using TOPO TA cloning kits (Invitrogen, Carlsbad, CA) according to the manufacturer's protocol. Products were amplified using plasmid-specific primers, visualized by gel electrophoresis and sequenced to verify the correct and complete sequence (Laboratory Services Department at the University of Guelph).

The standard curve used as a reference in $\mathrm{QPCR}$ ranged between $10^{1}$ and $10^{8}$ gene copies and had a PCR efficiency between 85 and $110 \%$, a slope between -3.1 and -3.7 , and an $R^{2}$ value $\geq 0.99$.

\section{Soil chemical analysis}

Samples were also analyzed for soil $\mathrm{pH}$ (1:1 soil to water method) (Carter and Gregorich, 2006), OM (WalkleyBlack method adapted to include dichromate as color indicator) (Handson et al., 1997), P (sodium bicarbonate method) (Olsen et al., 1954), $\mathrm{K}$ and $\mathrm{Mg}$ (ammonium acetate reference method OMAFRA Cations) by Agrifood laboratories (Guelph, Ontario, Canada) (Carter and Gregorich, 2006).

\section{Statistical analysis}

Analysis of variance (ANOVA) was performed using the PROC MIXED procedure in SAS (version 9.4, Statistical Analysis System, SAS Institute Inc., Cary, NC, USA, 2013) to assess the relationship within and between different treatments and sample times with AM 


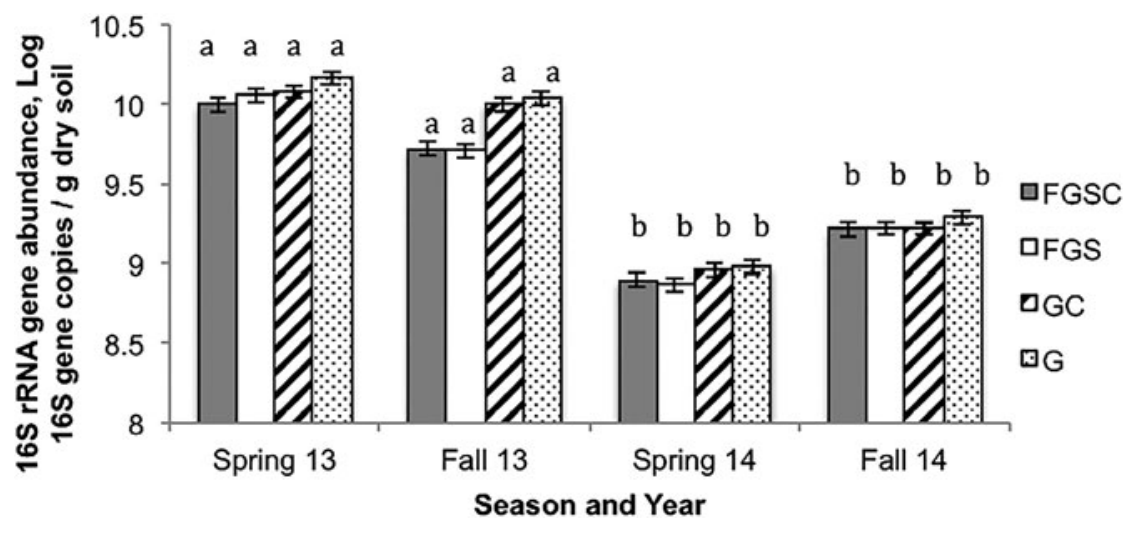

Figure 3. Average change in total soil bacterial gene abundance affected by four treatments over 2 yr in three sites across Guelph and Mississauga, Ontario, Canada. Different letters $(a, b)$ above bars indicate significantly different means within respective treatments.

fungal, total fungal, and bacterial abundances, and apple tree diameter as dependent variables. Using this model, variance was partitioned into fixed effects (treatments and season), the fixed effects interaction (treatment $\times$ season), random effect (site) and random effect interactions (site $\times$ treatment site $\times$ season site $\times$ season $\times$ treatment). The major assumptions of ANOVA include: the model is a linear additive model, the variables are independent of each other, and errors are randomly and normally distributed around a mean of zero and have a common variance. These assumptions were tested before analysis by examining patterns in errors using PROC PLOT (residual versus predicted plot), ShapiroWilks normality test and a comparison of covariance structures. A repeated measures analysis was used to account for the lack of variable independence which was due to repeated measurements over time on the experimental units and apple trees. The covariance structure compound symmetry was used. Lunds test was also conducted to test for outliers. Multiple means comparisons of soil microbial abundances, soil properties and tree measurements were compared using a Tukey adjustment $(\alpha=0.05)$. Significant differences of least-squared means were determined statistically significant based on $P$-values $(P=0.05$ to $<0.05)$ and marginally significant $(P=0.10-0.051)$.

\section{Results}

\section{Abundance of soil bacteria and fungi}

There were no significant differences between the abundances of total bacteria in the soil of the four treatments during any of the four respective sampling times. Changes in total bacterial abundance did occur over the 2 -yr experiment. All four treatments saw a significant decrease $(P>0.0001)$ in total soil bacteria abundance occurring between the fall 2013 and spring 2014 sampling events. Throughout the $2 \mathrm{yr}$ of the experiment the total bacterial abundance decreased in spring 2013 for treatments FGSC, FGS, GC and G from 9.99, 10.06, 910.08 and 10.17 to $9.21,9.22,9.22$ and $9.29 \pm 0.08 \mathrm{log}$ copies of $16 \mathrm{~S}$ gene per $\mathrm{g}$ of dried soil respectively in fall 2014 (Figure 3).

The abundance of total fungi in the soils also changed significantly $(P>0.0001)$ over time, though in the opposite pattern to the total bacterial abundance. In spring 2013, treatments FGSC, FGS, GC and G had log copies of ITS 14 gene sequence $( \pm 0.15)$ per $g$ of dried soil of $2.62,2.83,2.87$ and 3.05 , which increased over the $2 \mathrm{yr}$ to $4.74,4.69,4.69$ and 4.83 , respectively in fall 2014 (Figure 4). Similar to the total bacterial abundance measurements, there were no significant effects of any of the four treatments on total fungal abundance within any of the four sampling periods.

Changes in the abundance of AMF reflected those seen for total bacterial abundance with AMF abundance significantly declining $(P<0.005)$ over the 2 yr of the experiment, across all treatments. In spring 2013, treatments FGSC, FGS, GC and G had log copies of AML gene sequence $( \pm 0.55)$ per $g$ of dried soil of $5.83,236.14,5.86$ and 6.13 , which decreased over the $2 \mathrm{yr}$ to $4.13,4.11,4.50$ and 4.49, respectively, in fall 2014 (Figure 5). As with total bacterial abundance and total fungal abundance, AMF abundance saw no significant effects from the four treatments during any of the four sampling events.

\section{Tree growth}

Although all apple tree trunk circumferences showed growing trends, only FGSC treatments averaged over all sites had a significant effect on circumference over $2 \mathrm{yr}$ $(P<0.04)$, growing from $2.31 \pm 0.88 \mathrm{~cm}$ in spring 2013 to $6.34 \pm 0.88 \mathrm{~cm}$ in fall 2014 (Figure 6). Trees in FGS treatments averaged across all sites marginally increased in circumference from spring 2013 to fall 2014 by 3.44 $\pm 0.88 \mathrm{~cm}(P<0.079)$. The only significant difference $(P$ $<0.048$ ) between treatments in apple tree trunk circumference occurred in fall 2014, for the treatments FGSC $(6.3412 \pm 0.3 \mathrm{~cm})$ and $\mathrm{G}(5.03 \pm 0.3 \mathrm{~cm})$. 


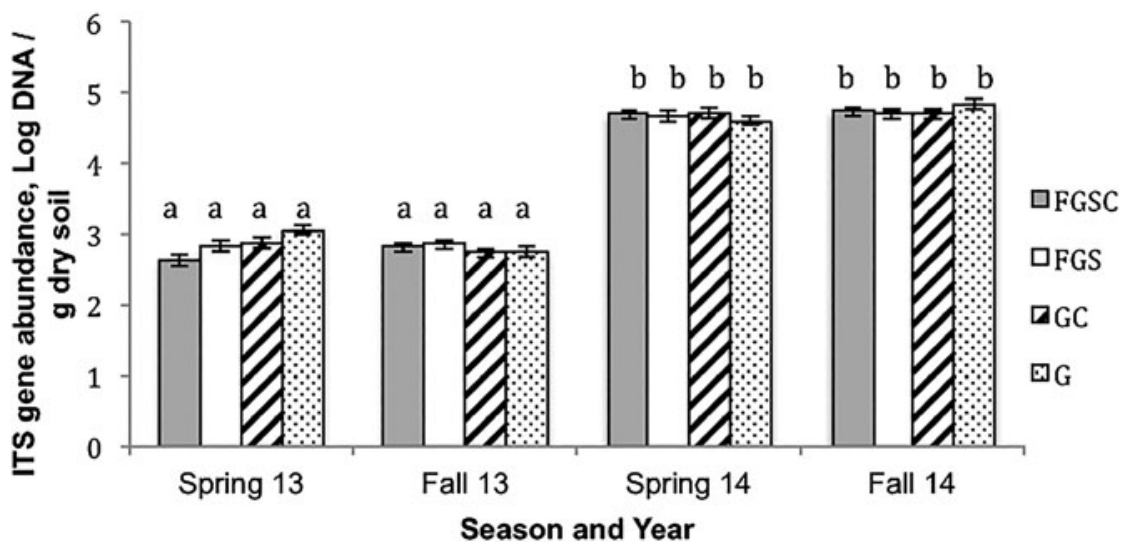

Figure 4. Average change in total soil fungi gene abundance affected by four treatments over 2 yr in three sites across Mississauga and Guelph, Ontario, Canada. Different letters $(a, b)$ above bars indicate significantly different means within respective treatments.

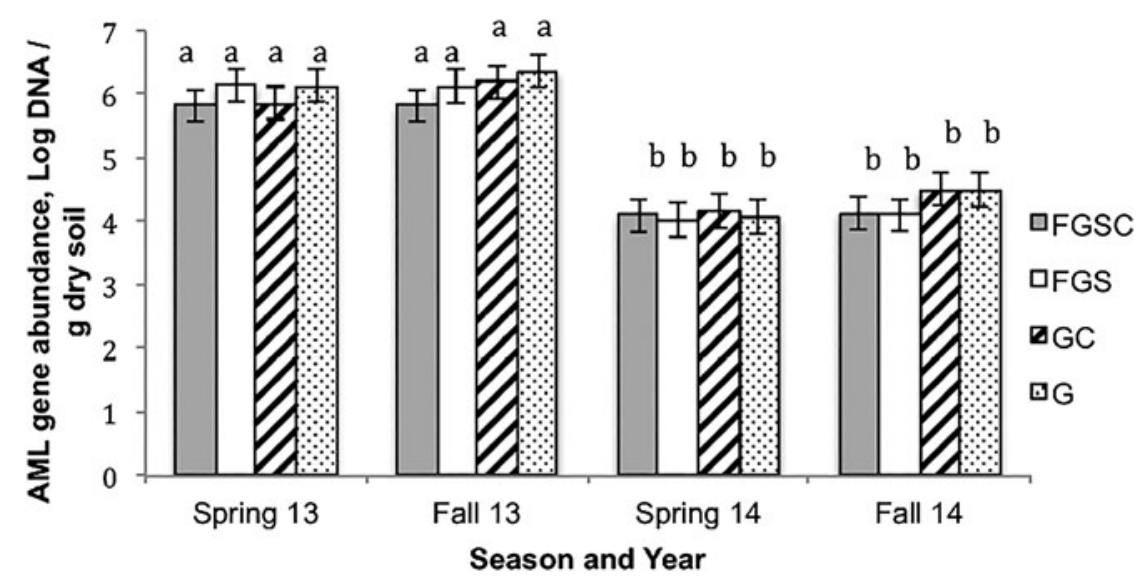

Figure 5. Average change in soil arbuscular mycorrhizal fungi gene abundance affected by four treatments over 2 yr in three sites across Mississauga and Guelph, Ontario, Canada. Different letters (a, b) above bars indicate significantly different means within respective treatments over time.

\section{Soil nutrients}

There were no significant differences in any soil chemistry measurements at any specific sampling time or over the entire experiment (Table 2).

\section{Discussion}

All orchard floor management treatments contributed to significant shifts in abundance of all studied soil microbes throughout the first two establishing years, from spring 2013 to fall 2014.

All treatments respectively increased total fungi abundance and decreased total bacteria abundance without significant differences between treatments. This resulted in a higher total fungi: total bacteria ratio $(\mathrm{F}: \mathrm{B})$ for all treatments in 2014 compared with 2013. Continuous vegetative cover (e.g., permanent cover crop or living ground cover) without tillage and varied complex organic matter inputs that contain high $\mathrm{C}$ concentrations have been acknowledged as factors contributing to a higher F:B (Unger et al., 2013). Unger et al. (2013) compared tree-based intercropping systems with vegetative strips of grass and annual crop systems, all of which were planted in 1991. They showed a similar lack of significant difference in overall total soil microbial abundance between treatments in 2009; however, significant shifts of specific species occurred within total bacterial and fungal communities. For example, the tree-based intercropping system soil had 23\% more anaerobic bacteria and 35\% more AMF compared with annual crop systems, whereas tree-based intercropping systems and VGS supported the same amounts of AMF, total bacteria and total fungi. Differences between vegetated strips of grass, tree-based intercropping systems and annual crop systems were attributed to lack of tillage, C contributions from roots of continuous vegetative cover and more complex and varied organic matter 


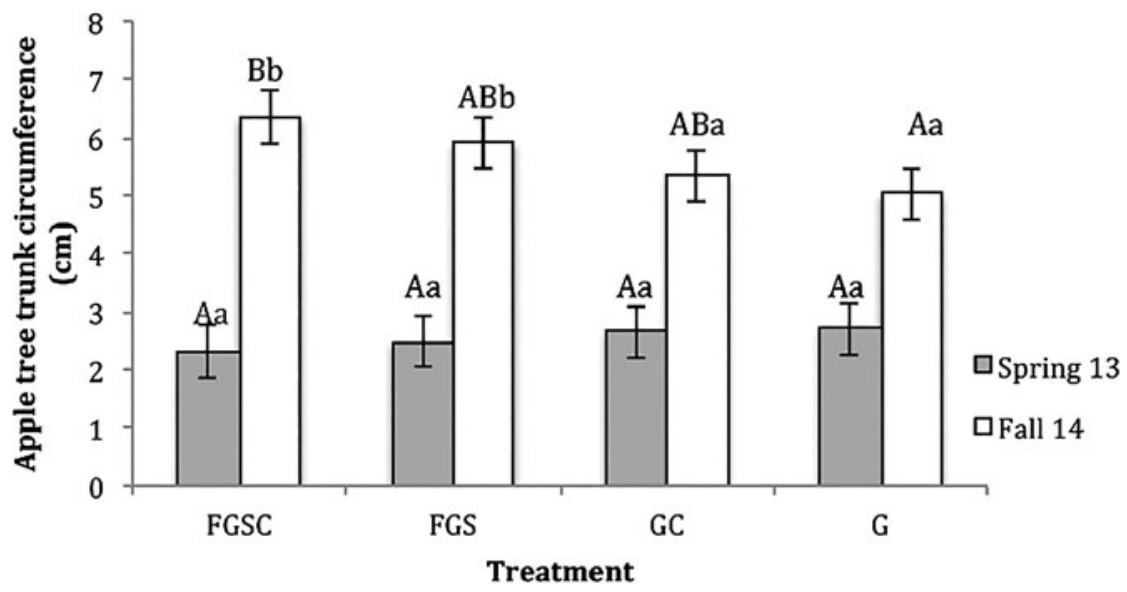

Figure 6. Average growth of apple tree trunk circumference in each of four treatments over 2 yr in three sites across Mississauga and Guelph, Ontario, Canada. Different letters ( $a, b)$ above bars indicate significantly different means within respective treatments, and the letters $(\mathrm{A}, \mathrm{B})$ indicate significantly different means between treatments.

Table 2. Average soil chemical analysis under four ground management systems over $2 \mathrm{yr}$ in three sites across Mississauga and Guelph, Ontario, Canada. Different letters (a, b, c) indicate significantly different means within respective treatments.

\begin{tabular}{|c|c|c|c|c|c|c|}
\hline Treatment & Time & $P( \pm 1.57 \mathrm{ppm})$ & K ( \pm 8.37 ppm) & $\mathrm{Mg}( \pm 32.63 \mathrm{ppm})$ & $\mathrm{pH}( \pm 0.06)$ & OM $( \pm 0.4 \%)$ \\
\hline \multirow[t]{2}{*}{ FGSC } & Spring 2013 & $19.97 \mathrm{a}$ & $97.35 \mathrm{a}$ & $259.24 \mathrm{a}$ & 7.39a & $4.21 \mathrm{a}$ \\
\hline & Fall 2014 & $20.28 \mathrm{a}$ & $108.38 \mathrm{a}$ & $263.48 \mathrm{a}$ & $7.47 \mathrm{a}$ & $5 \mathrm{a}$ \\
\hline \multirow[t]{2}{*}{ FGS } & Spring 2013 & $19.49 \mathrm{a}$ & $97.11 \mathrm{a}$ & $248.79 \mathrm{a}$ & $7.4 \mathrm{a}$ & $3.99 \mathrm{a}$ \\
\hline & Fall 2014 & $14.00 \mathrm{a}$ & $99.31 \mathrm{a}$ & $244.35 \mathrm{a}$ & $7.5 \mathrm{a}$ & $4.65 \mathrm{a}$ \\
\hline \multirow[t]{2}{*}{ GC } & Spring 2013 & $20.58 \mathrm{a}$ & $115.06 \mathrm{a}$ & $263.87 \mathrm{a}$ & $7.37 \mathrm{a}$ & $4.22 \mathrm{a}$ \\
\hline & Fall 2014 & $23.69 \mathrm{a}$ & $109.56 \mathrm{a}$ & $268.91 \mathrm{a}$ & $7.48 \mathrm{a}$ & $4.53 \mathrm{a}$ \\
\hline \multirow[t]{2}{*}{ G } & Spring 2013 & $17.87 \mathrm{a}$ & $90.95 \mathrm{a}$ & $252.02 \mathrm{a}$ & $7.51 \mathrm{a}$ & $3.98 \mathrm{a}$ \\
\hline & Fall 2014 & $15.23 \mathrm{a}$ & $101.99 \mathrm{a}$ & $252.74 \mathrm{a}$ & $7.4 \mathrm{a}$ & $4.54 \mathrm{a}$ \\
\hline
\end{tabular}

inputs. All four treatments in the present study had similar abundances of bacteria and fungi despite the differences in plant diversity, perhaps due to maintained perennial vegetation without tillage as in the above-mentioned study. However, the present study only ran for $2 \mathrm{yr}$ and, even with large annual internal additions of leaf litter matter in plots, measurable treatment effects on soil microbial and soil chemical properties may require a longer study period. SOM builds very slowly and more time may be needed to see significant changes. Measurement techniques that specifically capture changes in soil $\mathrm{C}$, such as labile $\mathrm{C}$ and/or total $\mathrm{C}$ Leco could be applied in the future (Wang and Anderson, 1998).

Conversely, as Cheng et al. (2013) demonstrated, forests with plant species that contribute larger amounts of $\mathrm{N}$ maintain a lower $\mathrm{F}: \mathrm{B}$. In the present study, there were no significant shifts in measured SOM in any of the treatments and over the $2 \mathrm{yr} \mathrm{N}$ levels were not measured. With $40 \%$ of plot areas planted to N-fixing plants, and with the application of composted manure, it would be beneficial to observe if treatments differ in regard to soil $\mathrm{N}$ (e.g., total $\mathrm{N}$, ammonium or nitrate) levels due to internal inputs, as well as seeing how microbial abundance is affected.

Also, Yao et al. (2005) suggested that a thatch layer of grass, which resulted from mowing over multiple years, might contribute a consistent supply of $\mathrm{C}$ to the soil through aboveground litter fall and root exudates. Based on these studies and the fact that both treatment types, forest garden-based and grass-based, shifted soil microbial abundance similarly it could be suggested that they are currently contributing similar amounts of $\mathrm{C}$ and $\mathrm{N}$ to the soil despite the differences in plant functional diversity (e.g., $\mathrm{N}$-fixing plants and biomass production) and species diversity.

Currently, we have observed that all treatments resulted in decreased AMF abundance over the first $2 \mathrm{yr}$, all of which occurred within an increase of total fungi abundance. As Bainard et al. (2011) mentioned in their review of AMF, there are few studies on how AMF are influenced by temperate agroforestry systems, but they concluded that incorporating trees into agricultural practices has a positive effect on soil life. Chifflot et al. (2009) found that AMF spore abundance was similar between systems of only poplar and poplar intercropped with 
soybean (22.96 and 22.70 spores $\mathrm{g}^{-1}$ soil, respectively). However, in the intercropped system, diversity of AMF was higher than the poplar only system ( 0.78 and 0.53 on the Shannon Weiner index, respectively) and the total spore count increased with increasing distance from the tree row, which is where more diverse plant roots interacted. In another study across two sites (Saint-Remi, Quebec and Guelph, Ontario), Lacombe et al. (2009) found higher concentrations of AMF in tree-based intercropping systems compared with conventional monocropping in two sites, Saint-Remi, Quebec (6.2 and $3.7 \mathrm{ng} \mathrm{g}^{-1}$ AMF fatty acids, respectively) and Guelph, Ontario (4.8 and $3.3 \mathrm{ng} \mathrm{g}^{-1}$ AMF fatty acids, respectively). Perhaps, in the present study, the level of plant diversity was greater prior to tillage and experimental treatment planting in spring 2013 which may have resulted in an initial higher read of AMF in 2013. It was also expected that increased diversity of plants in the forest garden-based treatments compared with grassbased treatments would cause higher AMF abundance, but it is possible that the limited mowing maintenance in the grass treatments allowed for increased plant diversity, which may have increased the AMF abundance.

Other studies have demonstrated the effects that organic amendments, such as compost and woodchips, can have on soil microbes. It seems as though the minimal compost additions $(2.7 \mathrm{~kg}$ per tree in spring 2013) in this present study created no significant change in soil microbial abundance compared with treatments without compost over 2 yr. Similarly, a study with three levels $(2.7,5.4$ and $8.1 \mathrm{~kg}$ total) and four split applications (April, early May mid-May, June) of incorporated compost applications at the base of newly established apple trees resulted in no significant changes in soil microbial activity ( $\mathrm{CO} 2$ respiration), which is indicative of microbe growth, or tree leaf nutrients between treatments (Hoagland et al., 2008). Conversely, a 3-yr study measured annual significant increases in microbial soil respiration, and marginal increases in microbial biomass, when compost was added and incorporated (dairy compost at the rate of $25 \mathrm{t} \mathrm{ha}^{-1}$ in spring 2008 and $12.5 \mathrm{tha}^{-1}$ in 2009) in respective cover crop treatments of rye ( 280 and $195 \mu \mathrm{g} \mathrm{CO} 2 \mathrm{~g}^{-1}$ dry soil with and without compost, respectively, in 2008) and vetch-rye mixture (180 and $138 \mu \mathrm{g} \mathrm{CO}^{2} \mathrm{~g}^{-1}$ dry soil with and without compost, respectively, in 2008) (Nair and Ngouajio, 2012).

These studies demonstrate that compost application can affect soil microbe community function and composition, but further research would help clarify appropriate application rates and the different forms of interactions that compost has with microbes (e.g., plant-microbe interactions or microbe-soil interactions). Measurements on how soil chemical properties, such as soil $\mathrm{C}$ and $\mathrm{N}$, are affected would also be important as these nutrients contribute to soil microbe function and abundance. Compost was also only applied once at the beginning of the present experiment, which may have limited its effects. Future studies could consider greater application rates across the whole plot or repeated applications.

Woodchips have been shown to affect soil microbes and other system variables. Yao et al. (2005) compared different ground management systems in a 9-yr-old apple orchard for their effects on bacterial and fungal activity, as well as changes in soil characteristics and tree growth. The mulch treatment, consisting of biennial spring applications of $15 \mathrm{~cm}$ layer of shredded hardwood bark mulch, compared with a treatment of grass mowed monthly had significantly greater SOM, soil P, calcium availability, soil cation exchange capacity, and soil $\mathrm{pH}$. The mulch treatment compared with the grass treatment had similar bacterial CFU and significantly less fungal CFU (Yao et al., 2005). Mulch treatments had more fine feeder-root biomass, higher soil $\mathrm{N}$ content, higher leaf $\mathrm{N}$ content, $15 \%$ larger trunk cross-sectional area (TCSA), and significantly higher fruit yields for 7 of 10 yr (1994-2003) compared with grass treatments (Yao et al., 2005). These differences were attributed to increased nutrient cycling due to increased soil biological activity, large additions of $\mathrm{N}$ in bark mulch $\left(162 \mathrm{~kg} \mathrm{~m}^{-2}\right.$ over the 12-yr experiment), $\mathrm{N}$ retention as a result of high $\mathrm{C}: \mathrm{N}$ and conserved soil moisture. The present study did not see any differences in soil chemical properties between FGS-based and grass-based treatments as the aforementioned study did, but that may have been due to the shorter time period. The FGSC and FGS treatments did see a significant increase in tree trunk size over the $2 \mathrm{yr}$ and significant difference compared with the $\mathrm{G}$ treatment in the last sampling period. Similarly to the abovementioned study, this may have been a result of the larger amount of wood chips in the FGS-based treatments, which were used to mulch all the plants in the entire plot compared with only around the apple tree in the $\mathrm{G}$ and $\mathrm{GC}$ treatments.

Hoagland et al. (2008) also found that $15 \mathrm{~cm}$ of woodchip mulch in newly established apple orchards resulted in increased tree growth. Mulched treatments caused a 298\% increase in TCSA, compared with cultivated, living leguminous mulch and living non-leguminous mulch treatments, which had 285, 180 and 196\% increases in TCSA, respectively, after 1 yr (2005-2006). Phosphorus was also highest in the mulched treatments, but it had the lowest $\mathrm{N} \%$ of all the treatments, which might have been caused by the incorporation of the wood chips into the soil in the fall.

In the present study FGS-based treatments, which had $15 \mathrm{~cm}$ of woodchip mulch applied over entire plot and unincorporated in spring 2013, saw increased tree growth (269 and $240 \%$ increase in trunk circumference for FGSC and FGS, respectively) over the $2 \mathrm{yr}$ compared with no significant tree growth in the grass-based treatments (196 and 190\% increase in trunk circumference for GC and G, respectively), which only had mulch on top of the tree root area (Figure 6). Our results follow 
similar trends to the two aforementioned studies regarding positive tree growth with woodchip mulch application. Conversely, the forest garden-based treatments, which had leguminous and non-leguminous perennial cover crops, saw no comparable disadvantage to tree growth, as Hoagland et al. (2008) did. Perhaps the spacing of supportive plants outside of the establishing apple tree root zone $(60 \mathrm{~cm}$ beyond roots at planting) and woodchip mulch application was an effective mix of understory management techniques that mitigated competition.

There were no changes in soil chemical properties: $\mathrm{P}, \mathrm{K}$, $\mathrm{Mg}, \mathrm{pH}$ or SOM; although FGSC treatments had on average the greatest non-significant increase in SOM, followed by FGS treatments. Perhaps over the time the unincorporated woodchip mulch will contribute more to the soil system, as it did in Yao et al.'s (2005) study.

\section{Conclusions}

The two establishment years of apple orchards designed as temperate FGSs and more common grass understory systems, both with and without compost amendments, saw similar increases in soil fungi abundance and similar decreases in soil bacteria abundance from spring 2013 to fall 2014. FGSC treatments had the greatest apple tree growth. FGS without compost treatments resulted in marginally significant tree growth. There were no significant differences between grass-based treatments due to compost addition. Soil nutrients ( $\mathrm{P}, \mathrm{K}, \mathrm{Mg}$ ) and $\mathrm{pH}$ had no changes in the first $2 \mathrm{yr}$ in any of the treatments. All treatments had increasing trends in SOM, but there were no significant increases.

This study was the first to report research results in establishing a temperate FGS. We conclude that FGSs can benefit apple orchards by increasing the growth of apple trees. We recommend additional research on: (1) microbial diversity under the two main systems for bacteria, archaea, fungi, and AMF, (2) nutrient cycling of $\mathrm{N}$-fixing plants and soil microbe interactions, (3) effect of compost applications, mechanically spread or grazing livestock, on tree growth and soil microbial communities, (4) long-term changes in soil chemical properties (e.g., SOM, P, C, N) and (5) intersecting with biodiversity measures, social goals and economic goals.

This study is in support of many ecological farmers across the globe whom are already practicing temperate forest gardening systems, and is a catalyst for future research. This management practice should be further studied as it relates to the importance of diversifying and strengthening our local markets, regenerating our shared environments, mitigating contributions to climate change, and shifting toward resilient, holistic systems. In Southern Ontario, Canada, there is opportunity for participatory research with farmers who are already practicing forest gardening systems on multiple scales.
Acknowledgments. I would like to acknowledge that this research was conducted on the traditional territory of the Attawandaron and the Mississaugas of the New Credit First Nations peoples, and offer respect to them and their ancestors. I hope that the food systems that support us can contribute to the reconciliation of the harm caused to your communities and our shared environment (Mother Nature). Ecological farmers in southern Ontario area who are practicing regenerative food production on the land that they are stewarding inspired this work. Thank you all and I hope this work can support you. I am extremely grateful to my co-advisors, Rene Van Acker and Ralph Martin, for their initial interest in this topic, and their generous financial, technical, and emotional support throughout this process. Your commitment to regenerative agriculture is inspiring! Thank you so much to the amazingly supportive folks at the School for Environmental Sciences: Kari Dunfield, who sat on my committee and greatly assisted in the whole process, Kamini Khosla, who provided so much lab support and laughter, Crystall McCall, who showed me "the ropes" of molecular analysis, and John Drummelsmith, who analyzed soil microbes with great dexterity! Armfuls of thanks to Ecosource in Mississauga for their donation of land and logistical support, to Martha and Martin from the Guelph Centre for Urban Organic Farming in Guelph for their donation of land and logistical support, and to Ignatius Farm for logistical support! So much love and thanks to my Mum, Dad, Sister, Brother, and Ilana for emotional and physical support over the two years. I give boundless appreciation for my housemates and friends who joined me on countless conversations, outdoor adventures, and board games when I felt challenged. To all of you who helped to set up and maintain this project, my heartfelt thanks! Thanks, also, to Arthur D. Latornell and family for their offering of a graduate scholarship in support of conservation and remediation. Finally, I acknowledge myself for committing to this project and following through with what I wanted to do. It took a lot of asking for help and self-care, and I did it!

\section{References}

Allen, M.F., Swenson, W., Querejeta, J.I., EgertonWarburton, L.M., and Treseder, K.K. 2003. Ecology of mycorrhizae: A conceptual framework for complex interactions among plants and fungi. Annual Review of Phytopathology 41:271-303.

Askegaard, M. and Eriksen, J. 2007. Growth of legume and nonlegume catch crops and residual-N effects in spring barley on coarse sand. Journal of Plant Nutrition and Soil Science 170: 773-780.

Bainard, L.D., Klironomos, J.N., and Gordon, A.M. 2011. Arbuscular mycorrhizal fungi in tree-based intercropping systems: A review of their abundance and diversity. Pedobiologia 54:57-61.

Bonfante, P. and Anca, I. 2009. Plants, mycorrhizal fungi, and bacteria: A network of interactions. Annual Review of Microbiology 63:63-83.

Brown, W. 2012. Roles of biodiversity in integrated fruit production in Eastern North American orchards. Agriculture and Forest Entomology 14:89-99.

Butt, S., Ramprasad, P., and Fenech, A. 2012. Changes in the Landscape of Southern Ontario, Canada since 1750: Impacts of European Colonization. Available at Web site http://projects.upei.ca/climate/publications/books-on-climate/ integrated-mapping-assessment-2005 (verified 3 February 2015).

Carter, M.R. and Gregorich, E.G. 2006. Soil Sampling and Methods of Analysis. 2nd ed. Taylor \& Francis Group, Florida. 
Cheng, F., Peng, X., Zhao, P., Yuan, J., Zhong, C., Cheng, Y., Cui, C., and Zhang, S. 2013. Soil microbial biomass basal respiration and enzyme activity of main forest types in the Qinling Mountains. PLoS ONE 8(6):e67353. doi: 10.1371/journal.pone.0067353

Chifflot, V.C., Rivest, D., Olivier, A., Cogliastro, A., and Khasa, D. 2009. Molecular analysis of arbuscular mycorrhizal community structure and spores distribution in treebased intercropping and forest systems. Agriculture Ecosystems and the Environment 131:32-39.

Crawford, M. 2012. Creating a Forest Garden: Working with Nature to Grow Edible Crops. UIT Cambridge Ltd, Cambridge.

Ferguson, R.S. and Lovell, S.T. 2014. Permaculture for agroecology: Design, movement, practice and worldview. A review. Agronomy for Sustainable Development 34:251-274.

Fierer, N., Jackson, J.A., Vilgalys, R., and Jackson, R.B. 2005. Assessment of soil microbial community structure by use of taxon-specific quantitative PCR assays. Applied Environmental Microbiology 71:4117-4120.

FliBbach, A., Oberholzer, H., Gunst, L., and Mäder, P. 2007. Soil organic matter and biological soil quality indicators after 21 years of organic and conventional farming. Agriculture Ecosystems and the Environment 1118:273-284.

Gardes, M. and Bruns, T.D. 1993. ITS primers with enhanced specificity for basidiomycetes - application to the identification of mycorrhizae and rusts. Molecular Ecology 2:113-118.

Gardes, M., White, T.J., Fortin, J.A., Bruns, T.D., and Taylor, J. W. 1990. Identification of indigenous and introduced symbiotic fungi in ectomycorrhizae by amplification of nuclear and mitochondrial ribosomal DNA. Canadian Journal of Botany 69:180-190.

Government of Canada 2015. Canadian Climate Normal: 1981-2010 Climate Normal \& Averages. Available at Web site http://climate.weather.gc.ca/climate_normals/index_ e.html\#1981 (verified 20 February 2015).

Granatstein, D. and Sanchez, E. 2009. Research knowledge and needs for orchard floor management in organic tree fruit systems. International Journal of Fruit Science 7:257-281.

Handson, D., Kotuby-Amacher, J., and Miller, R.O. 1997. Soil analysis: Western states proficiency testing program for 1996. Fresenius Journal of Analytical Chemistry 360:348-350.

Hirsch, P.R., Mauchline, T.H., and Clark, I.M. 2010. Culture-independent molecular techniques for soil microbial ecology. Review of Soil Biology and Biochemistry 42:878-887.

Hoagland, L, Carpenter-Boggs, L, Granatstein, D., Mazzola, M., Smith, J., Peryea, F., and Reganold, J.P. 2008. Orchard floor management effects on nitrogen fertility and soil biological activity in a newly established organic apple orchard. Biology and Fertility of Soils 45:11-18.

Jacke, D. and Toensmeier, E. 2005. Edible Forest Gardens, Vol. 1. Chelsea Green, Vermont.

Jackson, W. 2002. Natural systems agriculture: A truly radical alternative. Agriculture Ecosystems Environment 88:111-117.

Janick, J. 2003. Horticultural Reviews: Wild Apple and Fruit Trees of Central Asia. Vol. 29. Wiley \& Sons, New York.

Jose, S. 2009. Agroforestry for ecosystem services and environmental benefits: An overview. Agroforestry Systems 76:1-10.

Kimmins, J.P. 2004. Forest Ecology: A foundation for Sustainable Forest Management and Environmental ethics in Forestry, 3rd ed. Upper Saddle River, New Jersey.

Lacombe, S., Bradley, R.L., Chantel, H., and Beaulieu, C. 2009. Do tree-based intercropping systems increase the diversity and stability of soil microbial communities? Agriculture Ecosystems and the Environment 131:25-31.

Lee, J., Lee, S., and Young, P.W. 2008. Improved PCR primers for the detection and identification of arbuscular mycorrhizal fungi. FEMS Microbiology Ecology 65:339-349.

Leinfelder, M.M. and Merwin, I.A. 2006. Management strategies for apple replant disease. New York Fruit Quarterly 14:39-42.

Nair, A. and Ngouajio, M. 2012. Soil microbial biomass, functional microbial diversity and nematode community structure as affected by cover crops and compost in an organic vegetable production system. Applied Soil and Ecology, 58: $45-55$.

Nemeth, D.D., Wagner-Riddle, C., and Dunfield, K.E. 2014. Abundance and gene expression in nitrifier and denitrifier communities associated with a field scale spring thaw $\mathrm{N}_{2} \mathrm{O}$ flux event. Soil Biology and Biochemistry 73:1-9.

Nerlich, K., Graeff-Honninger, S., and Claupeinm, W. 2013. Agroforestry in Europe: A review of the disappearance of traditional systems and development of modern agroforestry practices, with emphasis on experiences in Germany. Agroforestry Systems 87:475-492.

Olsen, S.R., Cole, C.V., Watanabe, F.S., and Dean, L.A. 1954. Estimation of Available Phosphorus Soils by Extraction with Sodium Bicarbonate. US Department of Agriculture, Washington, DC, Circular 939.

Shortt, K.B. and Vamosi, S.M. 2012. A review of the biology of the weedy Siberian peashrub, Caragana arborescnes, with an emphasis on its potential effects in North America. Botanical Studies 53:1-8.

Smith, S.E. and Smith, F.A. 2011. Mycorrhizas in plant nutrition and growth: New paradigms from cellular to ecosystem scales. Annual Review of Plant Biology 62:227-250.

Thevathasan, N.V. and Gordon, A.M. 2004. Ecology of tree intercropping systems in the north temperate region: Experiences from Southern Ontario. Agroforestry Systems 61:257-268.

Tomich, T.P., Brodt, S., Ferris, H., Galt, R., Horwath, W.R., and Kebreab, E. 2011. Agroecology: A review from a globalchange perspective. Annual Review of Environment and Resources 36:193-222.

Unger, I.M., Goyne, K.W., Kremer, R.J., and Kennedy, A.C. 2013. Microbial community diversity in agroforestry and grass vegetative filter strips. Agroforestry Systems 87:395-402.

Uprety, Y., Asselin, H., Dhakal, A., and Julien, N. 2012. Traditional use of medicinal plants in the boreal forest of Canada: A review and perspectives. Journal of Ethnobiology and Ethnomedicine 8:7.

Wang, D. and Anderson, D.W. 1998. Direct measurement of organic carbon content in soils by the Leco CR-12 carbon analyzer. Communications in Soil Science and Plant Analysis 29(1-2):15-21.

Welbaum, G.E., Sturz, A.V., Dong, Z., and Nowak, J. 2004. Managing soil microorganisms to improve productivity of agro-ecosystems. Critical Review of Plant Science 23:175-193.

Whiteside, M.D., Digman, M.A., Gratton, E., and Treseder, K.K. 2012. Organic nitrogen uptake by arbuscular mycorrhizal fungi in a boreal forest. Soil Biology and Biochemistry 55:7-13.

Wiersum, K.F. 2004. Forest gardens as an intermediate land-use system in the nature-culture continuum: Characteristics and future potential. Agroforestry Systems, 61:123-134.

Wotherspoon, A. 2014. Quantification of Carbon Gains and Losses for Five Tree Species in a 25-year Old Tree-based 
Intercropping System in Southern Ontario, Canada. University of Guelph, Canada.

Wu, J. and Hobbs, R. 2002. Key issues and research priorities in landscape ecology: An idiosyncratic synthesis. Landscape Ecology 17:355-365.

Yao, S., Merwin, I.A., Bird, G.W., Abawi, G.S., and Thies, J.E. 2005. Orchard floor management practices that maintain vegetative or biomass groundcover stimulate soil microbial activity and alter soil microbial community composition. Plant and Soil 271:377-389.

Zak, D.R., Holmes, W.E., White, D.C., Peacock, A.D., and Tilman, D. 2003. Plant diversity, soil microbial communities, and ecosystem function: Are there any links? Ecology 84: 2042-2050. 